\title{
Diurnal variations of polar organic tracers in summer forest aerosols: A case study of a Quercus and Picea mixed forest in Hokkaido, Japan
}

\author{
PINGQING FU and KIMITAKA KaWAMURA* \\ Institute of Low Temperature Science, Hokkaido University, Sapporo 060-0819, Japan \\ (Received August 10, 2010; Accepted March 4, 2011)
}

\begin{abstract}
We investigated the summertime formation of secondary organic aerosols (SOA) via the oxidation of isoprene, $\alpha / \beta$ pinene and $\beta$-caryophyllene in a Quercus crispula and Picea glehnii mast mixed forest located at Hokkaido University Uryu Experimental Forest in Japan. Biogenic SOA tracers and other polar organic compounds (e.g., sugars and aromatic acids) in time-resolved (4 h) aerosol samples (13-15 August, 2001) were characterized using gas chromatography-mass spectrometry. Isoprene SOA tracers including 2-methyltetrols and $\mathrm{C}_{5}$-alkane triols were found to be the most abundant compound class (32-219 $\mathrm{ng} \mathrm{m}^{-3}$, average $113 \mathrm{ng} \mathrm{m}^{-3}$ ), followed by sugars/sugar alcohols. A strong diurnal variation of isoprene oxidation products was observed with higher concentrations during late afternoon-early evening. However, there were no clear trends for $\alpha / \beta$-pinene and $\beta$-caryophyllene oxidation products. The daytime formation of isoprene SOA correlated well with increased temperature and solar radiation, suggesting a temperature- and/or light-dependent emission of isoprene in the forest followed by photochemical oxidation. Levoglucosan, a biomass burning tracer, showed no correlation with biogenic SOA tracers, indicating that biomass burning contribute little to the formation of biogenic SOA at the sampling site. A significant decrease in the concentrations of biogenic SOA tracers and other polar organic tracers was found during a fog event. Using a tracer-based method, we conclude that the contributions of secondary organic carbon (SOC) from isoprene oxidation products to organic carbon were more significant than those of $\alpha / \beta$-pinene and $\beta$ caryophyllene oxidation products. The total SOC accounts for 5.7-34\% (average 17\%) of OC. This suggests that the emission of biogenic volatile organic compounds followed by subsequent oxidation plays an important role in the formation of SOA over the Quercus and Picea mixed forest.
\end{abstract}

Keywords: secondary organic aerosol, isoprene, 2-methyltetrols, levoglucosan, BVOCs

\section{INTRODUCTION}

Vegetation releases a variety of biogenic volatile organic compounds (BVOCs) into the atmosphere, including isoprene, monoterpenes, sesquiterpenes, as well as oxygenated hydrocarbons (e.g., acetone and methanol) (Guenther et al., 1995). On a global scale, the emissions of BVOCs have been estimated to be $1150 \mathrm{Tg}^{-1} \mathrm{rr}^{-1}$, among which isoprene is the most important species with an estimated emission rate of $c a .600 \mathrm{Tg} \mathrm{yr}^{-1}$ (Guenther et al., 2006). Modeling studies have shown that isoprene could be a significant source of atmospheric organic matter globally (Henze and Seinfeld, 2006). Liao et al. (2007) reported that $58.2 \%$ and $37.3 \%$ of biogenic SOA in the United States are formed from the oxidation of isoprene and monoterpenes, respectively.

Although there are evidences for marine production of isoprene (Bonsang et al., 1992; Yokouchi et al., 1999) and monoterpenes (Yassaa et al., 2008), terrestrial veg-

*Corresponding author (e-mail: kawamura@lowtem.hokudai.ac.jp)

Copyright $@ 2011$ by The Geochemical Society of Japan. etation is the main source of BVOCs in the atmosphere. Their emissions vary geographically depending on vegetation type (Guenther et al., 2006). Measurements of BVOC emissions have been conducted on several hundred individual species (Kesselmeier and Staudt, 1999; Duhl et al., 2008). For example, isoprene emission has been reported from both broad-leaved (e.g., Quercus, Populus, and Eucalyptus) and needle-leaved (e.g., Picea and Abies) trees (see Pacifico et al., 2009 and references therein), which are generally $\mathrm{C} 3$ plants. The emission of isoprene is mainly controlled by light intensity and temperature (Yokouchi and Ambe, 1988; Guenther et al., 1995). The light-dependence distinguishes isoprene emission from monoterpene emissions, which continue during nighttime (Pacifico et al., 2009).

In the past decade, considerable efforts have been devoted to understand secondary organic aerosol (SOA) formation from the photooxidation of BVOCs because SOA is an important component in the Earth's atmosphere (Hallquist et al., 2009 and references therein). SOA can influence the atmospheric radiation budget directly by scattering sunlight and indirectly by acting as cloud condensation nuclei (CCN) (Kanakidou et al., 2005). Polar 
organic tracers (e.g., 2-methyltetrols, pinic acid, 3hydroxyglutaric acid, and $\beta$-caryophyllinic acid) from the oxidation of BVOCs have been characterized in smog chamber experiments (Iinuma et al., 2004; Sato, 2008) and widely reported in ambient samples (e.g., Yu et al., 1999; Claeys et al., 2004a; Plewka et al., 2006; Szmigielski et al., 2007; Hu et al., 2008; Kourtchev et al., 2008b; Wang et al., 2008; Fu et al., 2009, 2010).

Moreover, studies have reported that oligmers (e.g., Kalberer et al., 2004) and other high molecular weight organic substances such as organosulfates (e.g., Liggio and Li, 2006; Iinuma et al., 2007) and humic-like substances (HULIS) may also contribute to SOA in the atmosphere. Recently, Jaoui et al. (2010) reported two new nitrogen-containing compounds (the structures are not identified) from isoprene oxidation under acidic conditions, which could be potentially served as tracers for isoprene SOA formation. In addition, highly time-resolved characterization of organic aerosol by using aerosol mass spectroscopy (AMS) (e.g., Hodzic et al., 2009) has been often reported in urban and rural sites as well as a continuous measurement of water-soluble organic carbon (WSOC) coupled to a particle-into-liquid sampler (PILS) (Miyazaki et al., 2006). These studies provide insights into the sources and processes that influence SOA production and their spatial and seasonal distributions. Aerosol organic carbon in forests is believed to be dominated by biogenic SOA, especially in summer when biological activities are maximized under intense sunlight and high ambient temperature conditions. However, studies on time-resolved diurnal variations of ambient SOA at a molecular level in the forest atmosphere are limited (Kavouras et al., 1999).

The purpose of this study is to characterize the SOA tracers that are derived from the atmospheric oxidation of isoprene, $\alpha / \beta$-pinene, and $\beta$-caryophyllene in an experimental forest dominated by Quercus crispula and Picea glehnii mast in Hokkaido, Japan. Diurnal trends of biogenic SOA tracers are compared with meteorological parameters and other polar organic compounds such as primary saccharides, hydroxyacids and biomass burning tracers (e.g., levoglucosan).

\section{SAMPLES AND Methods}

\section{Sample collection}

Total suspended particles (TSP) were collected from 13 to 15 August 2001 at a rural site in the Uryu Experimental Forest of Hokkaido University $\left(44.35^{\circ} \mathrm{N}\right.$, $142.25^{\circ} \mathrm{E}$, approximately $200 \mathrm{~km}$ north of Sapporo). Dominant plant species in the experimental forest are Quercus crispula (oak tree) and Picea glehnii mast (spruce tree). The sampling site is located approximately $1 \mathrm{~km}$ inside the nearest forest boundary. Time-resolved aero- sol particles were collected onto precombusted $\left(450^{\circ} \mathrm{C}\right.$, $6 \mathrm{~h})$ quartz fiber filters $(20 \times 25 \mathrm{~cm}$, Pallflex 2500QATUP) every $4 \mathrm{~h}(00: 15-03: 45,04: 15-07: 45,08: 15-11: 45$, $12: 15-15: 45,16: 15-19: 45$ and 20:15-23:45, local time) using a high-volume air sampler with a flow rate of 1.0 $\mathrm{m}^{3} \mathrm{~min}^{-1}$. The sampler was set at $3.5 \mathrm{~m}$ above the ground level where the canopy height was approximately $15 \mathrm{~m}$. The sample filter was placed in a precombusted clean glass jar with a Teflon-lined screw cap and stored in a dark freezer room at $-20^{\circ} \mathrm{C}$ prior to analysis.

\section{Extraction, derivatization, and GC/MS determination}

Filter aliquots were extracted three times for $10 \mathrm{~min}$ each with dichloromethane/methanol $(2: 1 ; \mathrm{v} / \mathrm{v})$ under ultrasonication. The solvent extracts were filtered through quartz wool packed in a Pasteur pipette, concentrated by the use of a rotary evaporator, and blown down to dryness with pure nitrogen gas. The extracts were then derivatized with $50 \mu \mathrm{l}$ of N,O-bis(trimethylsilyl)trifluoroacetamide (BSTFA) with $1 \%$ trimethylsilyl chloride and $10 \mu \mathrm{l}$ of pyridine at $70^{\circ} \mathrm{C}$ for $3 \mathrm{~h}$. After the reaction, derivatives were diluted by addition of $140 \mu \mathrm{l}$ of $n$-hexane containing $1.43 \mathrm{ng} \mu \mathrm{l}^{-1}$ of the internal standard ( $\mathrm{C}_{13} n$-alkane) prior to $\mathrm{GC} / \mathrm{MS}$ injection. GC/MS analyses of the samples were performed on a Hewlett-Packard model 6890 GC coupled to HewlettPackard model 5973 mass-selective detector (MSD). The derivatized sample was injected to GC in a splitless mode at an injector temperature of $280^{\circ} \mathrm{C}$. The GC separation was carried out on a DB-5MS fused silica capillary column (30 $\mathrm{m} \times 0.25 \mathrm{~mm}$ i.d., $0.25 \mu \mathrm{m}$ film thickness) with the $\mathrm{GC}$ oven temperature programmed from $50^{\circ} \mathrm{C}(2 \mathrm{~min})$ to $120^{\circ} \mathrm{C}$ at $15^{\circ} \mathrm{C} \mathrm{min}{ }^{-1}$ and then to $300^{\circ} \mathrm{C}$ at $5^{\circ} \mathrm{C} \mathrm{min}{ }^{-1}$ with final isothermal hold at $300^{\circ} \mathrm{C}$ for $16 \mathrm{~min}$. The mass spectrometer was operated in the electron ionization (EI) mode at $70 \mathrm{eV}$ and scanned in the $m / z$ range $50-650$. Data were processed with the Chemstation software. Individual compounds (TMS derivatives) were identified by comparison of mass spectra with those of authentic standards or literature data.

For the quantification of biomass burning tracers and some other polar organic tracers (hydroxy-/polyacids, aromatic acids, sugars and sugar alcohols, 3hydroxyglutaric, pinonic, norpinic, and pinic acids), their GC/MS response factors were determined using authentic standards. The concentrations of $\beta$-caryophyllinic acid (a diacid similar to pinic acid) were calculated assuming that the response factor of this acid is equivalent to that of pinic acid (Jaoui et al., 2007). Following fragment ions were used for the identification of biogenic SOA tracers: $\mathrm{m} / \mathrm{z} 219$ and 277 for 2-methyltetrols, $\mathrm{m} / \mathrm{z} 231$ for $\mathrm{C}_{5}$-alkene triols, $m / z 219$ and 203 for 2-methylglyceric acid, $m / z 171$ for pinic and pinonic acids, $m / z 349$ for 3-hydroxyglutaric acid, $m / z 405$ for 3-methyl-1,2,3-butanetricarboxylic acid 
(MBTCA), and $m / z 383$ for $\beta$-caryophyllinic acid. MBTCA, 2-methylglyceric acid, $\mathrm{C}_{5}$-alkene triols, and 2methyltetrols were quantitatively determined with a capillary GC (Hewlett-Packard, HP6890) equipped with a split/ splitless injector, fused-silica capillary column (HP-5, 25 $\mathrm{m} \times 0.2 \mathrm{~mm}$ i.d., $0.50 \mu \mathrm{m}$ film thickness), and a flame ionization detector (FID). The identification of the organic compounds by GC/FID was confirmed by GC/MS analysis. Meso-erythritol, a surrogate compound that was generally used for the quantification of 2-methyltetrols (e.g., Claeys et al., 2004a; Wang et al., 2008), was quantitatively determined by both GC/MS and GC/FID. The analytical error for the GC/MS and GC/FID analysis of meso-erythritol was $<5 \%$. Field blank filters were treated as real samples for quality assurance. The results showed no serious contamination (less than $1 \%$ of real samples). Recoveries for the authentic standards or surrogates that were spiked onto pre-combusted quartz filters $(n=3)$ and treated as a real sample were generally better than $80 \%$. The data reported here were corrected for the blanks but not for recoveries. Relative standard deviation of the concentrations based on duplicate analysis was generally $<10 \%$.

Organic carbon (OC) was measured using a Sunset Lab carbon analyzer, following the Interagency Monitoring of Protected Visual Environments (IMPROVE). Duplicate analyses of filter samples showed uncertainties of $\pm 10 \%$.

\section{RESUlts}

\section{Meteorological condition and general results}

During the sampling period, clear sky conditions were maintained without rainfall, although a fog event occurred in the morning of 15 August when the light intensity (wave length: approximately $300-2800 \mathrm{~nm}$ ) remained lower for ca. 1.5 hours (Fig. 1(a)). Ambient temperatures ranged from $9.3^{\circ} \mathrm{C}$ to $29.5^{\circ} \mathrm{C}$, whereas relative humidity ( $\mathrm{RH}$ ) ranged from $31.3 \%$ to $92.1 \%$ (see Fig. 1(b)). The wind speeds recorded at $3.5 \mathrm{~m}$ above ground level were $<0.01$ $\mathrm{m} \mathrm{s}^{-1}$, whereas at $10 \mathrm{~m}$ they ranged from 0.12 to $0.84 \mathrm{~m}$ $\mathrm{s}^{-1}$ (average $0.42 \mathrm{~m} \mathrm{~s}^{-1}$ ) (Matsunaga et al., 2003). Such a low wind speed indicates that local influences are rather more important than long-range atmospheric transport. Concentrations of organic carbon in the forest aerosols ranged from 1.6 to $6.7 \mu \mathrm{g} \mathrm{m}^{-3}\left(4.3 \mu \mathrm{g} \mathrm{m}^{-3}\right)$. The diurnal

Fig. 1. Diurnal variations of polar organic tracers detected in forest aerosols from northern Japan. (a) light intensity, (b) relative humidity (RH), ambient temperature $(T)$, and organic carbon (OC), (c) biogenic secondary organic aerosol tracers for isoprene, monoterpene and sesquiterpene oxidation, (d) sugars and sugar alcohols, (e) other polar organic acids (hydroxyIpolyacids and aromatic acids), and (f) biomass burning tracers. Shadows in the plots indicate nighttime.

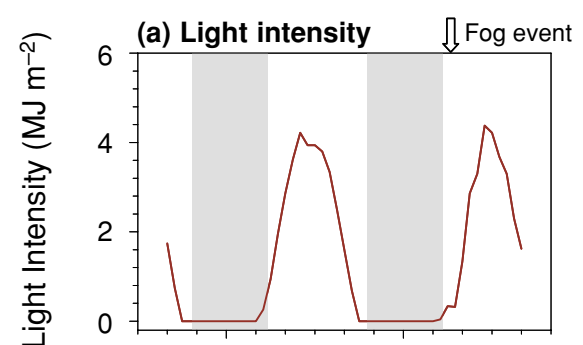

(b) $\mathrm{RH}, \mathrm{T}$, and organic carbon

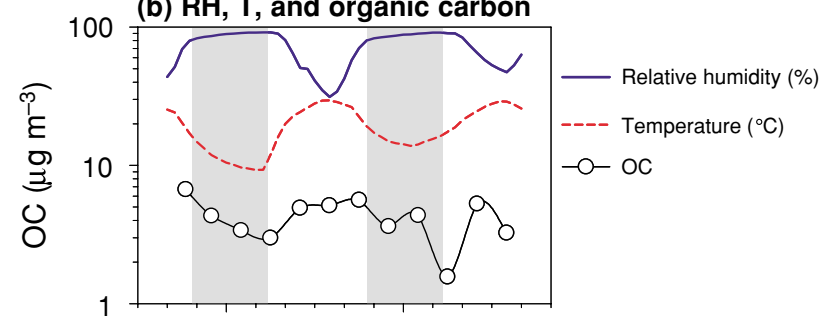

(c) Biogenic SOA tracers
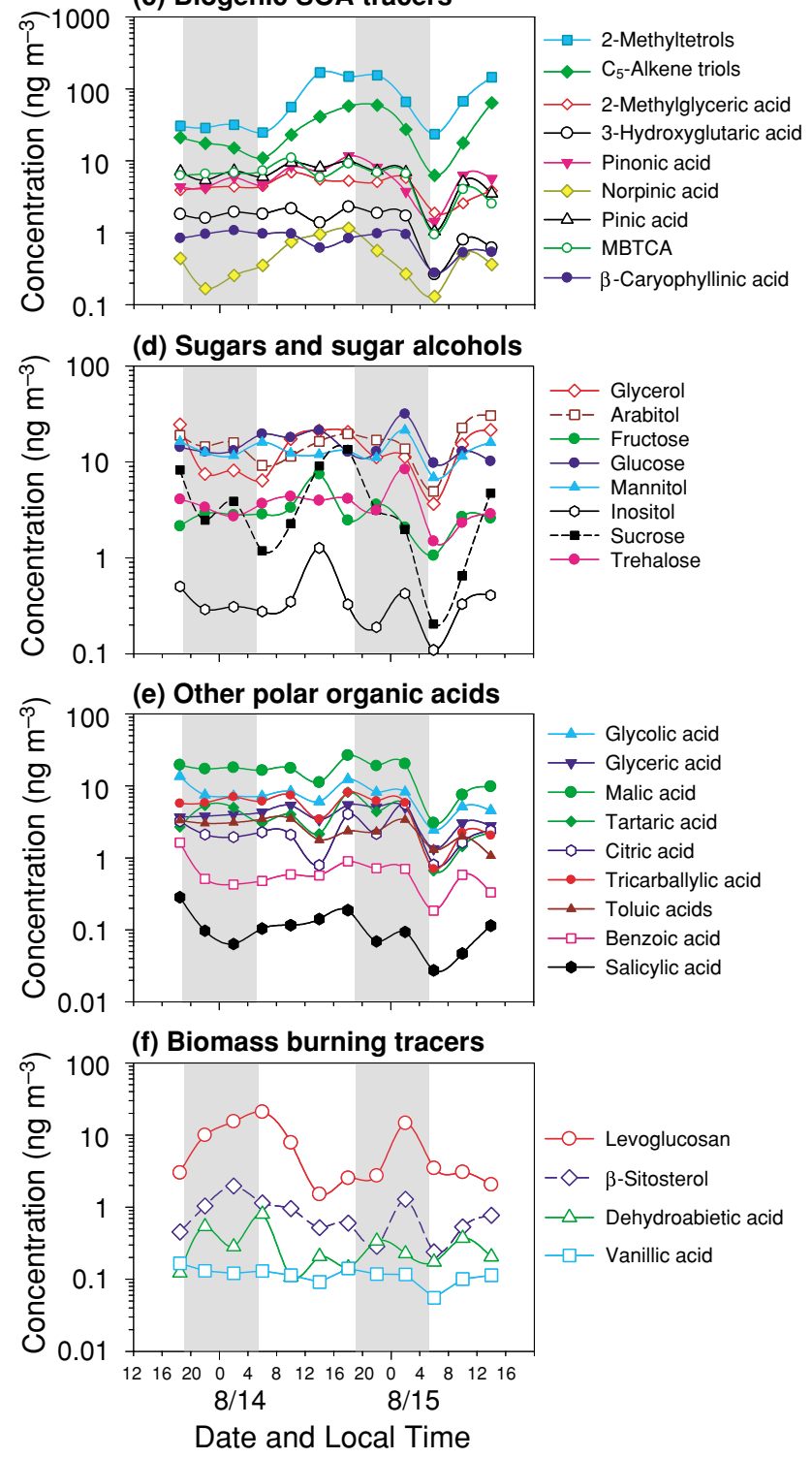

Fig. 1 . 
Table 1. Concentrations of biogenic secondary organic aerosol tracers and other polar organic compounds detected in the timeresolved atmospheric aerosols, $\left(\mathrm{ng} \mathrm{m}^{-3}\right)$

\begin{tabular}{|c|c|c|c|c|}
\hline Compound & mean & $\mathrm{std}^{\mathrm{a}}$ & $\min$ & $\max$ \\
\hline \multicolumn{5}{|l|}{ Isoprene SOA tracers } \\
\hline 2-Methylglyceric acid & 4.5 & 1.4 & 1.9 & 6.9 \\
\hline$\Sigma \mathrm{C}_{5}$-alkene triols ${ }^{\mathrm{b}}$ & 30 & 20 & 6.3 & 64 \\
\hline 2-Methylthreitol & 24 & 18 & 7.1 & 55 \\
\hline 2-Methylerythritol & 54 & 40 & 15 & 113 \\
\hline Subtotal & 113 & 77 & 32 & 219 \\
\hline \multicolumn{5}{|l|}{$\alpha / \beta$-Pinene SOA tracers } \\
\hline 3-Hydroxyglutaric acid & 9.2 & 3.8 & 1.6 & 14 \\
\hline Pinonic acid & 6.0 & 2.7 & 1.4 & 12 \\
\hline Norpinic acid & 0.5 & 0.3 & 0.1 & 1.2 \\
\hline Pinic acid & 6.4 & 2.5 & 1.0 & 10 \\
\hline MBTCA $^{\mathrm{c}}$ & 6.2 & 2.7 & 0.9 & 11 \\
\hline Subtotal & 28 & 11 & 5.1 & 46 \\
\hline \multicolumn{5}{|l|}{$\beta$-Caryophyllene SOA tracer } \\
\hline$\beta$-Caryophyllinic acid & 0.8 & 0.3 & 0.3 & 1.1 \\
\hline Total biogenic SOA tracers & 142 & 81 & 37 & 258 \\
\hline \multicolumn{5}{|l|}{ Hydroxy-/polyacids } \\
\hline Glycolic acid & 7.8 & 3.1 & 2.4 & 14 \\
\hline Salicylic acid & 0.1 & 0.1 & 0.03 & 0.3 \\
\hline Glyceric acid & 4.1 & 1.2 & 1.3 & 5.5 \\
\hline Malic acid & 16 & 6.3 & 3.0 & 26 \\
\hline Tartaric acid & 3.8 & 2.1 & 0.7 & 8.2 \\
\hline Citric acid & 2.5 & 1.2 & 0.8 & 5.6 \\
\hline Tricarballylic acid & 5.2 & 2.3 & 0.7 & 8.1 \\
\hline Subtotal & 39 & 15 & 9.0 & 65 \\
\hline \multicolumn{5}{|l|}{ Aromatic acids } \\
\hline Benzoic acid & 0.6 & 0.2 & 0.4 & 1.0 \\
\hline$o$-Toluic acid & 0.2 & 0.1 & 0.03 & 0.3 \\
\hline$m$-Toluic acid & 0.4 & 0.2 & 0.1 & 1.0 \\
\hline$p$-Toluic acid & 0.1 & 0.1 & 0.05 & 0.4 \\
\hline Subtotal & 1.3 & 0.5 & 0.6 & 2.7 \\
\hline
\end{tabular}

\begin{tabular}{|c|c|c|c|c|}
\hline Compound & mean & $\operatorname{std}^{\mathrm{a}}$ & $\min$ & $\max$ \\
\hline \multicolumn{5}{|l|}{ Biomass burning tracers } \\
\hline Levoglucosan & 7.3 & 6.5 & 1.5 & 21 \\
\hline Galactosan & 0.3 & 0.3 & 0.04 & 0.9 \\
\hline Mannosan & 1.0 & 0.5 & 0.2 & 2.0 \\
\hline Vanillic acid & 0.1 & 0.03 & 0.06 & 0.2 \\
\hline Dehydroabietic acid & 0.3 & 0.2 & 0.1 & 0.8 \\
\hline$\beta$-Sitosterol & 0.8 & 0.5 & 0.2 & 2.0 \\
\hline Subtotal & 9.7 & 7.8 & 3.4 & 26 \\
\hline \multicolumn{5}{|l|}{ Sugars and sugar alcohols } \\
\hline Glycerol & 14 & 7.0 & 3.7 & 25 \\
\hline Arabitol & 16 & 6.6 & 4.9 & 30 \\
\hline Fructose & 3.0 & 1.6 & 1.1 & 7.5 \\
\hline Glucose & 16 & 6.1 & 9.8 & 32 \\
\hline Mannitol & 13 & 3.6 & 6.9 & 21 \\
\hline Inositol & 0.4 & 0.3 & 0.1 & 1.3 \\
\hline Sucrose & 4.3 & 4.0 & 0.2 & 13 \\
\hline Trehalose & 3.7 & 1.7 & 1.5 & 8.4 \\
\hline Subtotal & 71 & 19 & 28 & 93 \\
\hline \multicolumn{5}{|l|}{ SOC yields ${ }^{\mathrm{d}}\left(\mu \mathrm{gC} \mathrm{m}^{-3}\right)$} \\
\hline Isoprene-derived SOC & 0.54 & 0.38 & 0.16 & 1.12 \\
\hline$\alpha$-Pinene-derived SOC & 0.12 & 0.05 & 0.02 & 0.20 \\
\hline$\beta$-Caryophyllene-derived SOC & 0.03 & 0.01 & 0.01 & 0.05 \\
\hline Subtotal & 0.69 & 0.39 & 0.20 & 1.28 \\
\hline $\mathrm{OC}\left(\mu \mathrm{g} \mathrm{m}^{-3}\right)$ & 4.3 & 1.4 & 1.6 & 6.7 \\
\hline $\mathrm{SOC}$ in $\mathrm{OC}(\%)$ & 17 & 9.2 & 5.7 & 34 \\
\hline
\end{tabular}

${ }^{a}$ std $=$ standard deviation

${ }^{b} C_{5}$-alkene triols: cis-2-methyl-1,3,4-trihydroxy-1-butene, trans-2-methyl-1,3,4-trihydroxy-1-butene, and 3-methyl-2,3,4-trihydroxy-1-butene. ${ }^{c}$ MBTCA: 3-methyl-1,2,3-butanetricarboxylic acid.

${ }^{d}$ The total mass concentrations of SOC produced by isoprene (2-methylglyceric acid and 2-methyltetrols were used), $\alpha / \beta$-pinene, and $\beta$ caryophyllene were calculated using a tracer-based method reported by Kleindienst et al. (2007).

variation of OC was characterized by a major peak during daytime and a sharp drop during the fog event (Fig. 1(b)). Table 1 presents the detected organic compounds including oxidation products of BVOCs. Isoprene SOA tracers were found to be the most abundant compound class (32-219 $\mathrm{ng} \mathrm{m}^{-3}$, average $113 \mathrm{ng} \mathrm{m}^{-3}$ ), followed by sugars/sugar alcohols (28-93 $\left.\mathrm{ng} \mathrm{m}^{-3}, 71 \mathrm{ng} \mathrm{m}^{-3}\right)$.

\section{Biogenic SOA tracers}

Isoprene (2-methyl-1,3-butadiene, $\mathrm{C}_{5} \mathrm{H}_{8}$ ) is emitted by many deciduous trees during daytime. It is highly reactive because of the $\mathrm{C}=\mathrm{C}$ bonds, which makes it susceptible to react with oxidants (e.g., $\mathrm{OH}, \mathrm{O}_{3}$, and $\mathrm{NO}_{3}$ ). Six compounds were so far identified as isoprene SOA tracers in the forest aerosols, including 2-methylglyceric acid, three $\mathrm{C}_{5}$-alkene triols, and two diastereoisomeric 2methyltetrols (2-methylthreitol and 2-methylerythritol). Concentration ranges of 2-methyltetrols were 22-168 ng $\mathrm{m}^{-3}\left(78 \mathrm{ng} \mathrm{m}^{-3}\right)$ with 2-methylerythritol being more abundant than 2 -methylthreitol by 2.2 -fold (Table 1 ). This ratio is similar to those observed in other studies (Claeys $e t$ al., 2004a; Ion et al., 2005; Cahill et al., 2006). The levels of 2-methyltetrols reported here are comparable to those of mid-latitudinal mountain aerosols from China (Wang et al., 2008). $\mathrm{C}_{5}$-Alkene triols, which are also photooxidation products of isoprene (Wang et al., 2005), 
were detected in all the samples with an average of $30 \pm$ $20 \mathrm{ng} \mathrm{m}^{-3}$. This level is higher than those reported in other studies from a Californian pine forest, USA (3.47 ng $\mathrm{m}^{-3}$ ) (Cahill et al., 2006), and Jülich, Germany (1.6-4.9 $\mathrm{ng} \mathrm{m}^{-3}$ ) (Kourtchev et al., 2008b). It is 2-3 orders of magnitude higher than those reported in the Arctic aerosols (Fu et al., 2009). Concentrations of 2-methylglyceric acid were $1.9-6.9 \mathrm{ng} \mathrm{m}^{-3}\left(4.5 \mathrm{ng} \mathrm{m}^{-3}\right)$. This acid is a possible oxidation product of methacrolein and methacrylic acid that are derived from isoprene (Claeys et al., 2004b; Surratt et al., 2006).

Pinonic, norpinic, and pinic acids are produced by the photooxidation of $\alpha / \beta$-pinene via reactions with $\mathrm{O}_{3}$ and $\mathrm{OH}$ radicals. Concentrations of pinonic, norpinic and pinic acids in this study ranged from $1.4-12 \mathrm{ng} \mathrm{m}^{-3}, 0.1-1.2$ $\mathrm{ng} \mathrm{m}^{-3}$ and $1.0-10 \mathrm{ng} \mathrm{m}^{-3}$, respectively (Table 1 ). Two novel compounds were recently identified in aerosols as 3-hydroxyglutaric acid (3-HG) (Claeys et al., 2007) and 3-methyl-1,2,3-butanetricarboxylic acid (MBTCA) (Szmigielski et al., 2007). Both 3-HG and MBTCA can be generated in smog chamber experiments of $\alpha$-pinene under the irradiation of UV in the presence of $\mathrm{NO}_{x}$. They are considered as later-generation products of the photooxidation of $\alpha / \beta$-pinene (Szmigielski et al., 2007; Kourtchev et al., 2009). Concentration ranges of 3-HG and MBTCA were 1.6-14 $\mathrm{ng} \mathrm{m}^{-3}\left(9.2 \mathrm{ng} \mathrm{m}^{-3}\right)$ and 0.9-11 $\mathrm{ng} \mathrm{m}^{-3}\left(6.2 \mathrm{ng} \mathrm{m}^{-3}\right)$, respectively.

$\beta$-Caryophyllene is one of the most abundant sesquiterpenes emitted from the plants and the most frequently reported (Duhl et al., 2008). $\beta$-Caryophyllinic acid, an ozonolysis or photo-oxidation product of $\beta$ caryophyllene (Jaoui et al., 2007), was identified in the forest samples ranging from 0.3 to $1.1 \mathrm{ng} \mathrm{m}^{-3}(0.8 \mathrm{ng}$ $\left.\mathrm{m}^{-3}\right)$.

\section{Biomass burning tracers and sugar compounds}

Levoglucosan (1,6-anhydro- $\beta$-D-glucopyranose), specifically formed by the pyrolysis of cellulose above $300^{\circ} \mathrm{C}$, has been recognized as an excellent tracer of biomass-burning (Simoneit et al., 1999). The concentration range of levoglucosan was $1.5-21 \mathrm{ng} \mathrm{m}^{-3}$ (7.3 ng $\mathrm{m}^{-3}$ ). In addition to levoglucosan, another two anhydrosugars (galactosan and mannosan) were identified in all the samples. The concentration ranges of galactosan and mannosan were $0.04-0.9 \mathrm{ng} \mathrm{m}^{-3}(0.3 \mathrm{ng}$ $\mathrm{m}^{-3}$ ) and $0.2-2.0 \mathrm{ng} \mathrm{m}^{-3}\left(1.0 \mathrm{ng} \mathrm{m}^{-3}\right)$, respectively. Vanillic acid is a biomass-burning tracer that can be detected in both hard and soft woods (Fine et al., 2001; Hays et al., 2005). Dehydroabietic acid is a diterpenoid, which is present in vegetation smoke both as natural and thermally altered products (Medeiros and Simoneit, 2008). $\beta$-Sitosterol is present in terrestrial higher plant leaves and can be emitted to the air via biomass burning processes (Simoneit, 2002).
Eight primary saccharides (glycerol, arabitol, fructose, glucose, mannitol, inositol, sucrose, and trehalose) were detected in the forest aerosols. Total concentrations of primary saccharides ranged from 28 to $93 \mathrm{ng} \mathrm{m}^{-3}$ (71 ng $\mathrm{m}^{-3}$ ) with the predominance of arabitol and glucose (Table 1). They have been used as tracers for primary biological aerosol particles (Graham et al., 2003; Medeiros et al., 2006; Bauer et al., 2008) and soil resuspension (Simoneit et al., 2004). Resuspended soil particles contain biological materials including pollen, fungi and bacteria.

\section{Other polar organic acids}

Seven hydroxy- or poly-acids were detected in the forest aerosols, including glycolic, salicylic, glyceric, malic, tartaric, citric, and tricarballylic acids with the dominance of malic acid. Glycolic acid (hydroxyacetic acid), the smallest $\alpha$-hydroxy acid, is hygroscopic and highly water-soluble. Salicylic acid (2-hydroxybenzoic acid) is a known plant hormone and can be directly emitted from plants into the atmosphere (Heiden et al., 1999). It is highly CCN active (Hartz et al., 2006), although its solubility is low. In the present study, the concentration range of salicylic acid was $0.03-0.3 \mathrm{ng} \mathrm{m}^{-3}\left(0.1 \mathrm{ng} \mathrm{m}^{-3}\right)$, which are lower than those reported in the tropical Indian aerosols $\left(0.1-1.1 \mathrm{ng} \mathrm{m}^{-3}\right)$ (Fu et al., 2010). However, they are much higher than those in the Arctic aerosols $\left(0.002-0.1 \mathrm{ng} \mathrm{m}^{-3}\right.$, average $\left.0.04 \mathrm{ng} \mathrm{m}^{-3}\right)$ ( $\mathrm{Fu}$ et al., 2009). Glyceric, malic, tartaric and citric acids are suggested as secondary oxidation products. For example, malic acid can be formed by the photo-oxidation of unsaturated fatty acids (Kawamura et al., 1996). The concentration range of tricarballylic acid was $0.7-8.1 \mathrm{ng}$ $\mathrm{m}^{-3}\left(5.2 \mathrm{ng} \mathrm{m}^{-3}\right)$, being similar to those reported in the tropical Indian aerosols (Fu et al., 2010).

Benzoic acid and three toluic acid isomers $\left(o^{-}, \mathrm{m}\right.$-, and $p-)$ were detected in the samples. Toluic acids can also be directly emitted from motor vehicular exhausts (Kawamura et al., 2000) or derived by the oxidation of xylene (Forstner et al., 1997). The total concentrations of these aromatic acids ranged from 0.6 to $2.7 \mathrm{ng} \mathrm{m}^{-3}$ (Table 1).

\section{Discussion}

Diurnal variations of biogenic SOA tracers: Predominance of isoprene SOA formation and influence of a fog event

Figure 1(c) presents diurnal variations of the biogenic SOA tracers. 2-Methyltetrols and $\mathrm{C}_{5}$-alkene triols showed very similar patterns with a continuous increase from early morning to late afternoon. Such an increase during daytime should be caused by the local emissions of isoprene followed by the photochemical oxidation. Matsunaga et 


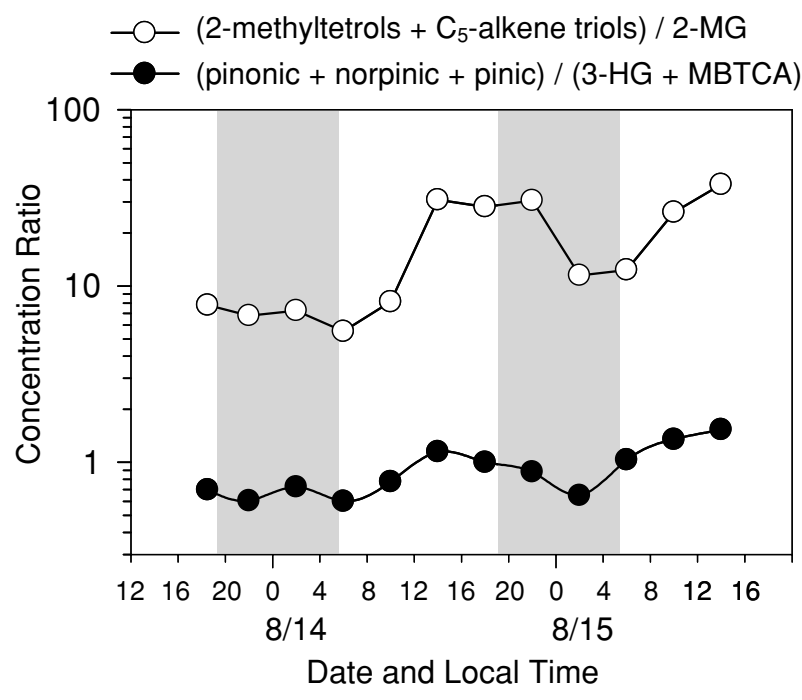

Fig. 2. Diurnal variations in the concentration ratios of isoprene and $\alpha / \beta$-pinene oxidation tracers.

al. (2003) reported diurnal variations of glycolaldehyde and hydroxyacetone in both gas and particle phases at the same sampling site during the same period. They found that the gaseous concentrations of these two compounds minimized early in the morning (02:00-06:00, local time) and increased rapidly to the maxima around noontime, suggesting that these semi-volatile carbonyls were vigorously produced and/or released in the forest atmosphere at daytime. The diurnal patterns of 2-methyltetrols and $\mathrm{C}_{5}$-alkene triols (Fig. 1(c)) are similar to those of particulate glycolaldehyde and hydroxyacetone measured during the same campaign (Matsunaga et al., 2003). They also reported a time lag of several hours between the peak concentrations of these carbonyls in gas and particle phases, indicating a gas-to-particle conversion probably through condensation and adsorption of gaseous compounds onto the pre-existing particles. The condensation/ adsorption processes should be accelerated in the evening when the ambient temperature decreased.

A good correlation between the concentrations of 2methyltetrols and $\mathrm{C}_{5}$-alkene triols $\left(R^{2}=0.84\right)$ was obtained in this study. Such a positive correlation has been reported in other studies (e.g., Cahill et al., 2006; Fu et al., 2010). $\mathrm{C}_{5}$-Alkene triols can be formed by acidcatalyzed ring opening of epoxydiol derivatives of isoprene (Wang et al., 2005). They can be converted to 2methyltetrols through acid-catalyzed hydrolysis.

2-Methylglyceric acid did not show a clear diurnal variation although a significant decrease was seen in the morning of 15 August when the fog event occurred (Fig. 1). A similar drop was observed for OC and other organic compounds, suggesting that the suspended particles in the

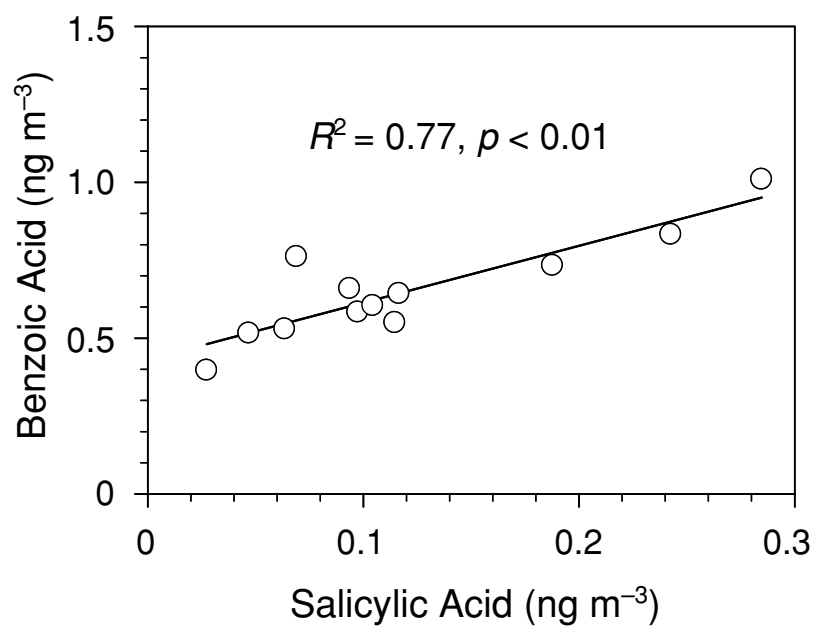

Fig. 3. A positive correlation between salicylic acid and benzoic acid detected in the forest aerosols.

forest atmosphere could be efficiently removed via wet deposition of fog droplets. The diurnal pattern of 2methylglyceric acid was different from those of 2methyltetrols and $\mathrm{C}_{5}$-alkene triols even though they are all derived from isoprene oxidation. Claeys et al. (2004b) pointed out that the formation of 2-methyltetrols can be explained through acid-catalyzed reaction of isoprene with hydrogen peroxide, while 2-methylglyceric acid can be formed by further oxidation of methacrolein and methacrylic acid, both gas-phase oxidation products of isoprene, via acid-catalyzed reaction with hydrogen peroxide in aqueous medium. Chamber experiments demonstrate that these polyols are mainly detected under low$\mathrm{NO}_{x}$ conditions (below $1 \mathrm{ppb}$ ), while 2-methylglyceric acid is a major product under high- $\mathrm{NO}_{x}$ conditions (Surratt et al., 2006).

3-Hydroxyglutaric, pinonic, pinic, 3-methyl-1,2,3butanetricarboxylic, and $\beta$-caryophyllinic acids show similar diurnal trends without daytime maxima (Fig. 1(c)). These diurnal patterns are different from those of isoprene SOA tracers such as 2-methyltetrols and $\mathrm{C}_{5}$-alkene triols except 2-methylglyceric acid (Fig. 1(c)). No clear diurnal variations were observed for $\alpha / \beta$-pinene SOA tracers, being in agreement with previous studies (Kourtchev et al., 2008a). Although the emissions of monoterpenes are temperature-dependant, they can also be emitted during nighttime and oxidized by $\mathrm{NO}_{3}$. Another possibility is that the formation of a shallow stable layer near the ground over the forest during nighttime may in part contribute to enhance the atmospheric levels of organic aerosols.

The concentration ratios of earlier- (pinic, pinonic and norpinic acids) to later-generation products (3-HG and MBTCA) of $\alpha / \beta$-pinene increased from early morning to 
late afternoon, and then decreased toward nighttime (Fig. 2 ), suggesting that the earlier-generation products or their precursors are continuously oxidized at night. Although the diurnal patterns of $\alpha / \beta$-pinene oxidation products are different from those of isoprene oxidation products, the concentration ratios of the sum of 2-methyltetrols and $\mathrm{C}_{5^{-}}$ alkene triols to 2-methylglyceric acid (2-MG) showed a very similar trend to that of $\alpha / \beta$-pinene SOA tracers (Fig. 2 ). As mentioned above, the formation pathway of $2-\mathrm{MG}$ is different from that of polyols. Such a diurnal pattern suggests that 2-MG may be a relatively later product of isoprene oxidation compared to 2-methyltetrols and $\mathrm{C}_{5^{-}}$ alkene triols. However, the formation mechanisms of isoprene SOA tracers are not completely understood yet (Carlton et al., 2009; Paulot et al., 2009; Claeys, 2010). It should be noted that there is a large difference in the concentrations of biogenic SOA tracers such as 2methyltetrols was observed between the nights of 13-14 August and 14-15 August. This suggests that the SOA yields in the ambient atmosphere depend on a number of factors such as the mixing ratios of BVOCs, $\mathrm{OH}$ and $\mathrm{NO}_{x}$ levels, organic aerosol loading, and the degree of oxidation (Carlton et al., 2009; Hallquist et al., 2009).

Hydroxy-/polyacids also showed diurnal patterns similar to those of $\alpha / \beta$-pinene SOA tracers (Fig. 1(e)). Interestingly, the diurnal pattern of salicylic acid was different from polyacids such as malic acid. A positive correlation was found between benzoic acid and salicylic acid (Fig. 3), indicating an intrinsic relation between these two aromatic acids. As mentioned earlier, salicylic acid can be directly emitted from plants (Heiden et al., 1999). Nakajima et al. (2008) reported that one possible source for salicylic acid in the atmosphere is the reaction of benzoic acid with hydroxyl radicals. Benzoic acid is emitted as a primary pollutant from fossil fuel combustion of motor vehicles (Kawamura and Kaplan, 1987; Rogge et al., 1993; Kawamura et al., 2000) and is produced by the photochemical oxidation of aromatic hydrocarbons (e.g., toluene) emitted from automobiles (Suh et al., 2003).

\section{Diurnal variations of primary saccharides}

Primary saccharides are an important class of organic compounds in atmospheric aerosols (Medeiros et al., 2006; Wan and Yu, 2007; Yttri et al., 2007; Fu et al., 2008). They are completely water-soluble and thus contribute to WSOC in aerosol. Sugar compounds are generally found to be more abundant in coarse fraction than the fine one (Fuzzi et al., 2007; Yttri et al., 2007), supporting that they are likely derived from primary biological aerosol particles. Graham et al. (2003) reported that fructose, sucrose and glucose showed higher daytime concentrations, which were explained by the specific daytime release of pollen, fern spores and other "giant" bioaerosols. Sucrose is the predominant sugar in the phloem of plants and is important in developing flower buds (Bieleski, 1995). Pashynska et al. (2002) reported that the atmospheric levels of inositol and sucrose and their contributions to OC were highest in early summer (June) owing to the developing leaves. As shown in Fig. 1(d), glycerol, arabitol, fructose, inositol and sucrose exhibited diurnal trends with daytime maxima. Thus, these sugars and sugar alcohols may be associated with specific daytime release of primary biological aerosol particles (PBAP) in the forest.

On the contrary, mannitol, glucose and trehalose didn't show clear diurnal patterns, which can be explained by the continuous emission of these compounds from microorganisms even at night. For example, mannitol, together with arabitol, has been reported as tracers for the airborne fungal spores (Bauer et al., 2008). Trehalose is present in a large variety of microorganisms (fungi, bacteria and yeast), and a few higher plants and invertebrates (Medeiros et al., 2006).

\section{Evaluation of the potential impact of biomass burning on SOA formation}

Biomass burning, together with biogenic SOA formation, is one of the major sources of organic aerosols in the atmosphere (de Gouw and Jimenez, 2009). Levoglucosan and other pyrolysis products of cellulose can be used as specific tracers for the emissions from biomass burning in atmospheric aerosols (Simoneit et al., 1999). In the present study, the concentration range of levoglucosan was $1.5-21 \mathrm{ng} \mathrm{m}^{-3}\left(7.3 \mathrm{ng} \mathrm{m}^{-3}\right)$. Such a level is even lower than those reported in marine aerosols over the western North Pacific (average $14 \mathrm{ng} \mathrm{m}^{-3}$ ) and off the Coast of East Asia (15 $\mathrm{ng} \mathrm{m}^{-3}$ ) (Mochida et al., 2003), suggesting that the effect of biomass burning on the forest aerosols was negligible during the sampling period. Furthermore, the temporal variations of biomass burning tracers (Fig. 1(f)) showed patterns different from those of biogenic SOA tracers. For example, levoglucosan showed a minimum concentration during daytime when concentrations of 2-methyltetrols and other isoprene oxidation products maximized. This difference again suggests that the effect of biomass burning on SOA formation was minor.

\section{Contributions of polar organic tracers to $O C$}

To better understand the SOA formation in the forest atmosphere, the contributions of isoprene, $\alpha / \beta$-pinene and $\beta$-caryophyllene oxidation products, and other polar organic compounds to OC were examined (Fig. 4). The contributions of isoprene SOA tracers to OC ranged from $0.4 \%$ to $3.0 \%(1.3 \%)$, which were 4 times higher than those of $\alpha / \beta$-pinene SOA tracers $(0.2-0.5 \%, 0.3 \%)$. Those of $\beta$-caryophyllinic acid to OC ranged from $0.007 \%$ to $0.02 \%(0.01 \%)$. Total SOA tracers are the most abundant 


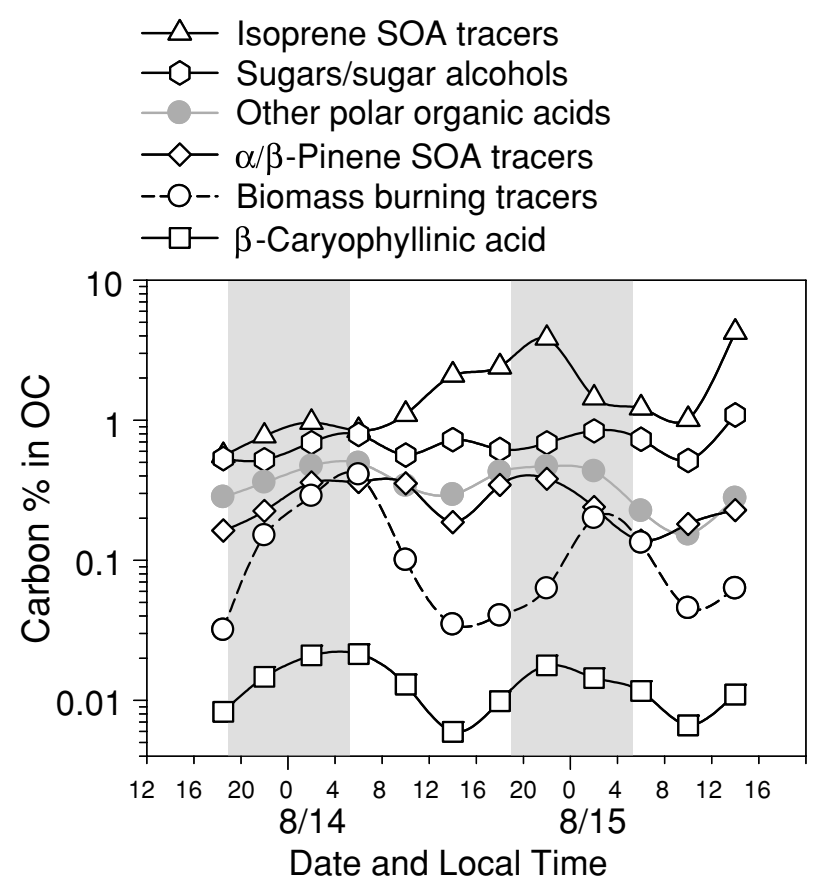

Fig. 4. Diurnal variations of the carbon \% of different organic compound classes in $O C$.

among the organic compound classes detected in this study. The mean contributions of total SOA tracers to OC were $1.6 \pm 0.9 \%$ with a maximum of $3.3 \%$. These values are similar to those ( $1.7 \%$ in average) reported in the boreal forest aerosols in Finland (Kourtchev et al., 2008a). Although the SOA tracers studied are oxidation products of biogenic VOCs, there are many unidentified organic compounds that can contribute to the formation of SOA (Hallquist et al., 2009), suggesting that the above contributions are only the minimum estimate and the actual contribution of BVOC to SOA should be much larger.

As shown in Fig. 4, the temporal variations of biomass burning tracers, $\alpha / \beta$-pinene SOA tracers, $\beta$-caryophyllinic acid, and other polar organic acids (hydroxy, aromatic and polyacids as mentioned in Table 1) relative to OC showed similar diurnal patterns each other with nighttime maxima and daytime minima. Such a trend suggests that during nighttime, higher relative humidity may favor the liquid phase formation of some polar organic compounds through heterogeneous reactions and that lower ambient temperature may enhance the condensation/adsorption processes. In contrast, the contributions of isoprene SOA tracers to OC exhibited a daytime maximum, while primary saccharides rather showed a flat pattern. These differences again suggest that isoprene oxidation products and primary biological particles are substantial components of forest organic aerosols in summer, particularly during daytime.
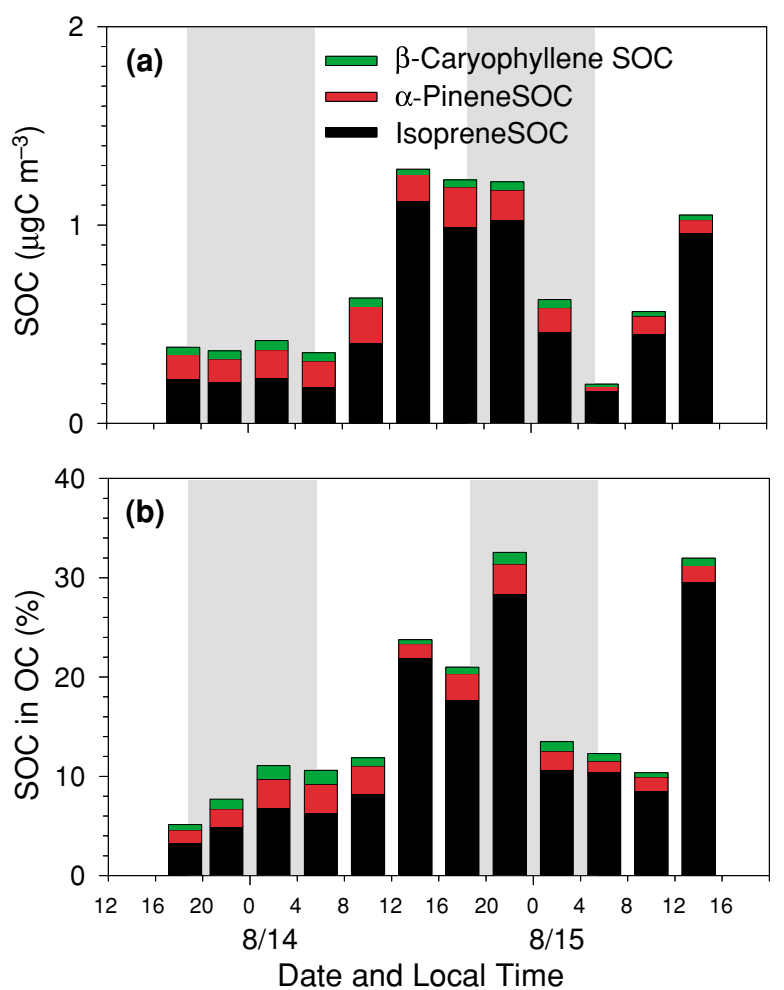

Fig. 5. Contributions of different hydrocarbon precursors to secondary organic carbon (SOC), and the percentages of $S O C$ in ambient $O C$ in individual samples.

\section{Estimates of ambient $S O C$, and $S O C$ in $O C$}

Based on the present dataset, we estimated the contributions of BVOCs to secondary organic carbon (SOC) using a tracer-based method proposed by Kleindienst $e t$ al. (2007). With the measured concentrations of tracer compounds in the forest aerosols and the laboratoryderived tracer mass fraction $\left(f_{\text {soc }}\right)$ factors of $0.155 \pm 0.039$ for isoprene, $0.231 \pm 0.111$ for $\alpha$-pinene and $0.0230 \pm$ 0.0046 for $\beta$-caryophyllene (Kleindienst et al., 2007), the contributions of these precursors to aerosol OC were calculated by the following equation:

$$
f_{\mathrm{soc}}=\frac{\sum_{i}\left[\text { tracer }_{i}\right]}{[\mathrm{soc}]}
$$

where $\sum_{i}\left[\right.$ tracer $\left._{i}\right]$ is the sum of the concentrations of the selected suite of tracers for a same BVOC precursor in $\mu \mathrm{g} \mathrm{m}^{-3}$. Although this technique was developed using a series of smog chamber experiments under relatively high $\mathrm{NO}_{x}$ conditions $(0.11-0.63 \mathrm{ppm})$ (Kleindienst et al., 2007), the $f_{\text {soc }}$ of $0.155 \pm 0.039$ for isoprene is similar to those $\left(f_{\text {soc,isoprene }}\right.$ from 0.117 to 0.231 , average 0.156$)$ in the absence of $\mathrm{NO}_{x}$ (Kleindienst et al., 2009). The simi- 
lar values suggest that the tracer-based method is applicable to the forest aerosols where the ambient $\mathrm{NO}_{x}$ levels are generally low. Although little is known about the differences of $f_{\text {soc }}$ values for $\alpha$-pinene and $\beta$-caryophyllene between high and low $\mathrm{NO}_{x}$ levels, we consider that the tracer-based method is the best technique available at present.

As shown in Table 1 and Fig. 5, the isoprene-based tracers (2-methylglyceric acid and 2-methyltetrols) were calculated to be 0.16 to $1.12 \mu \mathrm{gC} \mathrm{m}^{-3}\left(0.54 \mu \mathrm{gC} \mathrm{m}^{-3}\right)$. The contributions of $\alpha$-pinene and $\beta$-caryophyllene to SOC ranged from 0.02 to $0.20 \mu \mathrm{gC} \mathrm{m}^{-3}$ and 0.01 to 0.05 $\mu \mathrm{gC} \mathrm{m}{ }^{-3}$, respectively. These calculations show that isoprene was the major contributor to SOC in the Quercus and Picea mixed forest aerosols, which is reasonable because Quercus is a strong emitter of isoprene, although Picea emits both isoprene and monoterpenes (Pacifico et al., 2009 and references therein). The total SOC in the present forest aerosols ranged from 0.20 to $1.28 \mu \mathrm{gC}$ $\mathrm{m}^{-3}$ (average $0.69 \mu \mathrm{gC} \mathrm{m} \mathrm{m}^{-3}$ ), which correspond to 5.7$34 \%(17 \%)$ of the aerosol OC. It should be noted that Kleindienst et al. (2007) derived mass factions of SOA tracers by using ketopinic acid as the surrogate for all the SOA tracers. In this study, the SOA tracers were quantified using authentic standards together with some surrogates that were further quantified using GC/FID (see the Section of Samples and Methods). Nevertheless, we believe that the uncertainties between the two quantification methods should be minimal in terms of the uncertainties raised by the tracer-based approach itself (20$48 \%$ ) due to the standard deviation of $f_{\text {soc }}$ mentioned above (Kleindienst et al., 2007). Another point is that the isoprene and $\beta$-caryophyllene SOA tracers used in the tracerbased method are exactly same as those in Kleindienst et al. (2007). For the $\alpha / \beta$-pinene SOA tracers, however, five organic species were detected in this study, that is, 3hydroxyglutaric, pinonic, norpinic, pinic and 3-methyl1,2,3-butanetricarboxylic acids, although Kleindienst et al. (2007) reported a few additional $\alpha / \beta$-pinene SOA tracers, which were either undetectable or minor species in this study. The uncertainty raised by this point is estimated to be less than $30 \%$.

\section{Conclusions}

Biogenic SOA tracers, that is, the oxidation products of isoprene, $\alpha / \beta$-pinene and $\beta$-caryophyllene, together with other polar organic tracers, were determined in the aerosols collected from the mixed forest of Quercus crispula and Picea glehnii mast. 2-Methyltetrols and related isoprene oxidation products were found to be the dominant species among the identified organic compounds, especially during daytime. Total biogenic SOA tracers contributed $1.6 \pm 0.9 \%$ of the OC with a maxi- mum of $3.3 \%$ in daytime. Contribution of biomass burning to SOA production was found to be minor. However, primary saccharides could contribute $0.7 \pm 0.2 \%$ of the OC with a maximum of $1.1 \%$. In addition, secondary organic carbon that was estimated by a tracer-based method can contribute up to $34 \%$ (average 17\%) of OC in the forest aerosols, among which isoprene SOC was evaluated as the major contributor (average 13\%). This study demonstrates that the BVOC emission and its SOA formation processes play an important role in aerosol chemistry over a Quercus and Picea mixed forest in midlatitude.

Acknowledgments - This study was in part supported by the Japanese Ministry of Education, Culture, Sports, Science and Technology (MEXT) through grant-in-aid Nos. 17340166 and 19204055, and the Environment Research and Technology Development Fund (B-0903) of the Ministry of the Environment, Japan. The authors acknowledge M. Mochida, S. Matsunaga, I. Hiraga, O. Seki and other colleagues in the laboratory for their help during sample collection. The staffs of Uryu Experiment Forest are also acknowledged for the supply of meteorological data. Two anonymous reviewers are acknowledged for their valuable comments. P.F. appreciates the financial support for a research fellowship and Grant-in-Aid from the Japan Society for the Promotion of Science (JSPS, No. P08338).

\section{REFERENCES}

Bauer, H., Claeys, M., Vermeylen, R., Schueller, E., Weinke, G., Berger, A. and Puxbaum, H. (2008) Arabitol and mannitol as tracers for the quantification of airborne fungal spores. Atmos. Environ. 42, 588-593.

Bieleski, R. L. (1995) Onset of phloem export from senescent petals of daylily. Plant Physiol. 109, 557-565.

Bonsang, B., Polle, C. and Lambert, G. (1992) Evidence for marine production of isoprene. Geophys. Res. Lett. 19, 1129-1132.

Cahill, T. M., Seaman, V. Y., Charles, M. J., Holzinger, R. and Goldstein, A. H. (2006) Secondary organic aerosols formed from oxidation of biogenic volatile organic compounds in the Sierra Nevada Mountains of California. J. Geophys. Res., [Atmos.] 111, doi:10.1029/2006JD007178.

Carlton, A. G., Wiedinmyer, C. and Kroll, J. H. (2009) A review of secondary organic aerosol (SOA) formation from isoprene. Atmos. Chem. Phys. 9, 4987-5005.

Claeys, M. (2010) Comment on "Unexpected epoxide formation in the gas-phase photooxidation of isoprene". Science 327, 644 .

Claeys, M., Graham, B., Vas, G., Wang, W., Vermeylen, R., Pashynska, V., Cafmeyer, J., Guyon, P., Andreae, M. O., Artaxo, P. and Maenhaut, W. (2004a) Formation of secondary organic aerosols through photooxidation of isoprene. Science 303, 1173-1176.

Claeys, M., Wang, W., Ion, A. C., Kourtchev, I., Gelencsér, A. and Maenhaut, W. (2004b) Formation of secondary organic aerosols from isoprene and its gas-phase oxidation products through reaction with hydrogen peroxide. Atmos. 
Environ. 38, 4093-4098.

Claeys, M., Szmigielski, R., Kourtchev, I., Van Der Veken, P. and Vermeylen, R. (2007) Hydroxydicarboxylic acids: Markers for secondary organic aerosol from the photooxidation of $\alpha$-pinene. Environ. Sci. Technol. 41, 1628-1634.

de Gouw, J. and Jimenez, J. L. (2009) Organic aerosols in the Earth's atmosphere. Environ. Sci. Technol. 43, 7614-7618.

Duhl, T. R., Helmig, D. and Guenther, A. (2008) Sesquiterpene emissions from vegetation: a review. Biogeosciences 5, 761777.

Fine, P. M., Cass, G. R. and Simoneit, B. R. T. (2001) Chemical characterization of fine particle emissions from fireplace combustion of woods grown in the northeastern United States. Environ. Sci. Technol. 35, 2665-2675.

Forstner, H. J. L., Flagan, R. C. and Seinfeld, J. H. (1997) Secondary organic aerosol from the photooxidation of aromatic hydrocarbons: Molecular composition. Environ. Sci. Technol. 31, 1345-1358.

Fu, P. Q., Kawamura, K., Okuzawa, K., Aggarwal, S. G., Wang, G., Kanaya, Y. and Wang, Z. (2008) Organic molecular compositions and temporal variations of summertime mountain aerosols over Mt. Tai, North China Plain. J. Geophys. Res., [Atmos.] 113, D19107, doi:10.1029/2008JD009900.

Fu, P. Q., Kawamura, K., Chen, J. and Barrie, L. A. (2009) Isoprene, monoterpene, and sesquiterpene oxidation products in the high Arctic aerosols during late winter to early summer. Environ. Sci. Technol. 43, 4022-4028.

Fu, P. Q., Kawamura, K., Pavuluri, C. M., Swaminathan, T. and Chen, J. (2010) Molecular characterization of urban organic aerosol in tropical India: contributions of primary emissions and secondary photooxidation. Atmos. Chem. Phys. 10, 2663-2689.

Fuzzi, S., Decesari, S., Facchini, M. C., Cavalli, F., Emblico, L., Mircea, M., Andreae, M. O., Trebs, I., Hoffer, A., Guyon, P., Artaxo, P., Rizzo, L. V., Lara, L. L., Pauliquevis, T., Maenhaut, W., Raes, N., Chi, X., Mayol-Bracero, O. L., Soto-García, L. L., Claeys, M., Kourtchev, I., Rissler, J., Swietlicki, E., Tagliavini, E., Schkolnik, G., Falkovich, A. H., Rudich, Y., Fisch, G. and Gatti, L. V. (2007) Overview of the inorganic and organic composition of size-segregated aerosol in Rondonia, Brazil, from the biomass-burning period to the onset of the wet season. J. Geophys. Res., [Atmos.] 112, D01201, doi:10.1029/2005JD006741.

Graham, B., Guyon, P., Taylor, P. E., Artaxo, P., Maenhaut, W., Glovsky, M. M., Flagan, R. C. and Andreae, M. O. (2003) Organic compounds present in the natural Amazonian aerosol: Characterization by gas chromatography-mass spectrometry. J. Geophys. Res., [Atmos.] 108, D24, 4766, doi:4710.1029/2003JD003990.

Guenther, A., Hewitt, C. N., Erickson, D., Fall, R., Geron, C., Graedel, T., Harley, P., Klinger, L., Lerdau, M., Mckay, W. A., Pierce, T., Scholes, B., Steinbrecher, R., Tallamraju, R., Taylor, J. and Zimmerman, P. (1995) A global model of natural volatile organic compound emissions. J. Geophys. Res. 100, 8873-8892.

Guenther, A., Karl, T., Harley, P., Wiedinmyer, C., Palmer, P. I. and Geron, C. (2006) Estimates of global terrestrial isoprene emissions using MEGAN (Model of Emissions of
Gases and Aerosols from Nature). Atmos. Chem. Phys. 6, 3181-3210.

Hallquist, M., Wenger, J. C., Baltensperger, U., Rudich, Y., Simpson, D., Claeys, M., Dommen, J., Donahue, N. M., George, C., Goldstein, A. H., Hamilton, J. F., Herrmann, H., Hoffmann, T., Iinuma, Y., Jang, M., Jenkin, M. E., Jimenez, J. L., Kiendler-Scharr, A., Maenhaut, W., McFiggans, G., Mentel, T. F., Monod, A., Prevot, A. S. H., Seinfeld, J. H., Surratt, J. D., Szmigielski, R. and Wildt, J. (2009) The formation, properties and impact of secondary organic aerosol: current and emerging issues. Atmos. Chem. Phys. 9, 5155-5235.

Hartz, K. E. H., Tischuk, J. E., Chan, M. N., Chan, C. K., Donahue, N. M. and Pandis, S. N. (2006) Cloud condensation nuclei activation of limited solubility organic aerosol. Atmos. Environ. 40, 605-617.

Hays, M. D., Fine, P. M., Geron, C. D., Kleeman, M. J. and Gullett, B. K. (2005) Open burning of agricultural biomass: Physical and chemical properties of particle-phase emissions. Atmos. Environ. 39, 6747-6764.

Heiden, A. C., Hoffmann, T., Kahl, J., Kley, D., Klockow, D., Langebartels, C., Mehlhorn, H., Sandermann, H., Jr., Schraudner, M., Schuh, G. and Wildt, J. (1999) Emission of volatile organic compounds from ozone-exposed plants. Ecol. Appl. 9, 1160-1167.

Henze, D. K. and Seinfeld, J. H. (2006) Global secondary organic aerosol from isoprene oxidation. Geophys. Res. Lett. 33, doi:10.1029/2006GL025976.

Hodzic, A., Jimenez, J. L., Madronich, S., Aiken, A. C., Bessagnet, B., Curci, G., Fast, J., Lamarque, J.-F., Onasch, T. B., Roux, G., Schauer, J. J., Stone, E. A. and Ulbrich, I. M. (2009) Modeling organic aerosols during MILAGRO: importance of biogenic secondary organic aerosols. Atmos. Chem. Phys. 9, 6949-6982.

Hu, D., Bian, Q., Li, T. W. Y., Lau, A. K. H. and Yu, J. Z. (2008) Contributions of isoprene, monoterpenes, $\beta$-caryophyllene, and toluene to secondary organic aerosols in Hong Kong during the summer of 2006. J. Geophys. Res., [Atmos.] 113, D22206, doi:10.1029/2008JD010437.

Iinuma, Y., Böge, O., Gnauk, T. and Herrmann, H. (2004) Aerosol-chamber study of the $\alpha$-pinene $/ \mathrm{O}_{3}$ reaction: influence of particle acidity on aerosol yields and products. Atmos. Environ. 38, 761-773.

Iinuma, Y., Müller, C., Berndt, T., Böge, O., Claeys, M. and Herrmann, H. (2007) Evidence for the existence of organosulfates from $\beta$-pinene ozonolysis in ambient secondary organic aerosol. Environ. Sci. Technol. 41, 66786683.

Ion, A. C., Vermeylen, R., Kourtchev, I., Cafmeyer, J., Chi, X., Gelencsér, A., Maenhaut, W. and Claeys, M. (2005) Polar organic compounds in rural $\mathrm{PM}_{2.5}$ aerosols from K-puszta, Hungary, during a 2003 summer field campaign: Sources and diel variations. Atmos. Chem. Phys. 5, 1805-1814.

Jaoui, M., Lewandowski, M., Kleindienst, T. E., Offenberg, J. H. and Edney, E. O. (2007) $\beta$-Caryophyllinic acid: An atmospheric tracer for $\beta$-caryophyllene secondary organic aerosol. Geophys. Res. Lett. 34, L05816, doi:10.1029/ 2006GL028827.

Jaoui, M., Corse, E. W., Lewandowski, M., Offenberg, J. H., 
Kleindienst, T. E. and Edney, E. O. (2010) Formation of organic tracers for isoprene SOA under acidic conditions. Atmos. Environ. 44, 1798-1805.

Kalberer, M., Paulsen, D., Sax, M., Steinbacher, M., Dommen, J., Prevot, A. S. H., Fisseha, R., Weingartner, E., Frankevich, V., Zenobi, R. and Baltensperger, U. (2004) Identification of polymers as major components of atmospheric organic aerosols. Science 303, 1659-1662.

Kanakidou, M., Seinfeld, J. H., Pandis, S. N., Barnes, I., Dentener, F. J., Facchini, M. C., Van Dingenen, R., Ervens, B., Nenes, A., Nielsen, C. J., Swietlicki, E., Putaud, J. P., Balkanski, Y., Fuzzi, S., Horth, J., Moortgat, G. K., Winterhalter, R., Myhre, C. E. L., Tsigaridis, K., Vignati, E., Stephanou, E. G. and Wilson, J. (2005) Organic aerosol and global climate modelling: a review. Atmos. Chem. Phys. 5, 1053-1123.

Kavouras, I. G., Mihalopoulos, N. and Stephanou, E. G. (1999) Secondary organic aerosol formation vs primary organic aerosol emission: In situ evidence for the chemical coupling between monoterpene acidic photooxidation products and new particle formation over forests. Environ. Sci. Technol. 33, 1028-1037.

Kawamura, K. and Kaplan, I. R. (1987) Motor exhaust emissions as a primary source for dicarboxylic acids in Los Angels ambient air. Environ. Sci. Technol. 21, 105-110.

Kawamura, K., Sempéré, R., Imai, Y., Fujii, Y. and Hayashi, M. (1996) Water soluble dicarboxylic acids and related compounds in Antarctic aerosols. J. Geophys. Res., [Atmos.] 101, 18721-18728.

Kawamura, K., Steinberg, S. and Kaplan, I. R. (2000) Homologous series of $\mathrm{C}_{1}-\mathrm{C}_{10}$ monocarboxylic acids and $\mathrm{C}_{1}-\mathrm{C}_{6}$ carbonyls in Los Angeles air and motor vehicle exhausts. Atmos. Environ. 34, 4175-4191.

Kesselmeier, J. and Staudt, M. (1999) Biogenic volatile organic compounds (VOC): an overview on emission, physiology and ecology. J. Atmos. Chem. 33, 23-88.

Kleindienst, T. E., Jaoui, M., Lewandowski, M., Offenberg, J. H., Lewis, C. W., Bhave, P. V. and Edney, E. O. (2007) Estimates of the contributions of biogenic and anthropogenic hydrocarbons to secondary organic aerosol at a southeastern US location. Atmos. Environ. 41, 8288-8300.

Kleindienst, T. E., Lewandowski, M., Offenberg, J. H., Jaoui, M. and Edney, E. O. (2009) The formation of secondary organic aerosol from the isoprene $+\mathrm{OH}$ reaction in the absence of $\mathrm{NO}_{x}$. Atmos. Chem. Phys. 9, 6541-6558.

Kourtchev, I., Ruuskanen, T. M., Keronen, P., Sogacheva, L., Dal Maso, M., Reissell, A., Chi, X., Vermeylen, R., Kulmala, M., Maenhaut, W. and Claeys, M. (2008a) Determination of isoprene and $\alpha-/ \beta$-pinene oxidation products in boreal forest aerosols from Hyytiälä, Finland: diel variations and possible link with particle formation events. Plant Biol. 10, $138-149$.

Kourtchev, I., Warnke, J., Maenhaut, W., Hoffmann, T. and Claeys, M. (2008b) Polar organic marker compounds in $\mathrm{PM}_{2.5}$ aerosol from a mixed forest site in western Germany. Chemosphere 73, 1308-1314.

Kourtchev, I., Copolovici, L., Claeys, M. and Maenhaut, W. (2009) Characterization of atmospheric aerosols at a forested site in Central Europe. Environ. Sci. Technol. 43,
4665-4671.

Liao, H., Henze, D. K., Seinfeld, J. H., Wu, S. and Mickley, L. J. (2007) Biogenic secondary organic aerosol over the United States: Comparison of climatological simulations with observations. J. Geophys. Res., [Atmos.] 112, doi:10.1029/2006JD007813.

Liggio, L. and Li, S.-M. (2006) Organosulfate formation during the uptake of pinonaldehyde in acidic sulfate aerosols. Geophys. Res. Lett. 33, L13808, doi:13810.11029/ 12006 GL026079.

Matsunaga, S., Mochida, M. and Kawamura, K. (2003) Growth of organic aerosols by biogenic semi-volatile carbonyls in the forestal atmosphere. Atmos. Environ. 37, 2045-2050.

Medeiros, P. M. and Simoneit, B. R. T. (2008) Source profiles of organic compounds emitted upon combustion of green vegetation from temperate climate forests. Environ. Sci. Technol. 42, 8310-8316.

Medeiros, P. M., Conte, M. H., Weber, J. C. and Simoneit, B. R. T. (2006) Sugars as source indicators of biogenic organic carbon in aerosols collected above the Howland Experimental Forest, Maine. Atmos. Environ. 40, 1694-1705.

Miyazaki, Y., Kondo, Y., Takegawa, N., Komazaki, Y., Fukuda, M., Kawamura, K., Mochida, M., Okuzawa, K. and Weber, R. J. (2006) Time-resolved measurements of water-soluble organic carbon in Tokyo. J. Geophys. Res., [Atmos.] 111, D23206, doi:23210.21029/22006JD007125.

Mochida, M., Kawamura, K., Umemoto, N., Kobayashi, M., Matsunaga, S., Lim, H.-J., Turpin, B. J., Bates, T. S. and Simoneit, B. R. T. (2003) Spatial distributions of oxygenated organic compounds (dicarboxylic acids, fatty acids, and levoglucosan) in marine aerosols over the western Pacific and off the coast of East Asia: Continental outflow of organic aerosols during the ACE-Asia campaign. J. Geophys. Res., [Atmos.] 108, D23, 8638, doi:10.1029/2002JD003249.

Nakajima, H., Okada, K., Kuroki, Y., Nakama, Y., Handa, D., Arakaki, T. and Tanahara, A. (2008) Photochemical formation of peroxides and fluorescence characteristics of the water-soluble fraction of bulk aerosols collected in Okinawa, Japan. Atmos. Environ. 42, 3046-3058.

Pacifico, F., Harrison, S. P., Jones, C. D. and Sitch, S. (2009) Isoprene emissions and climate. Atmos. Environ. 43, 61216135.

Pashynska, V., Vermeylen, R., Vas, G., Maenhaut, W. and Claeys, M. (2002) Development of a gas chromatographic/ ion trap mass spectrometric method for the determination of levoglucosan and saccharidic compounds in atmospheric aerosols. Application to urban aerosols. J. Mass Spectrom. 37, 1249-1257.

Paulot, F., Crounse, J. D., Kjaergaard, H. G., St. Clair, J. M., Seinfeld, J. H. and Wennberg, P. O. (2009) Unexpected epoxide formation in the gas-phase photooxidation of isoprene. Science 325, 730-733.

Plewka, A., Gnauk, T., Bruggemann, E. and Herrmann, H. (2006) Biogenic contributions to the chemical composition of airborne particles in a coniferous forest in Germany. Atmos. Environ. 40, S103-S115.

Rogge, W. F., Hildemann, L. M., Mazurek, M. A., Cass, G. R. and Simoneit, B. R. T. (1993) Sources of fine organic aerosol. 2. Noncatalyst and catalyst-equipped automobiles and 
heavy-duty diesel trucks. Environ. Sci. Technol. 27, 636651.

Sato, K. (2008) Detection of nitrooxypolyols in secondary organic aerosol formed from the photooxidation of conjugated dienes under high- $\mathrm{NO}_{x}$ conditions. Atmos. Environ. 42, 6851-6861.

Simoneit, B. R. T. (2002) Biomass burning-a review of organic tracers for smoke from incomplete combustion. Appl. Geochem. 17, 129-162.

Simoneit, B. R. T., Schauer, J. J., Nolte, C. G., Oros, D. R., Elias, V. O., Fraser, M. P., Rogge, W. F. and Cass, G. R. (1999) Levoglucosan, a tracer for cellulose in biomass burning and atmospheric particles. Atmos. Environ. 33, 173-182.

Simoneit, B. R. T., Elias, V. O., Kobayashi, M., Kawamura, K., Rushdi, A. I., Medeiros, P. M., Rogge, W. F. and Didyk, B. M. (2004) Sugars-dominant water-soluble organic compounds in soils and characterization as tracers in atmospheric particulate matter. Environ. Sci. Technol. 38, 59395949.

Suh, I., Zhang, R., Molina, L. T. and Molina, M. J. (2003) Oxidation mechanism of aromatic peroxy and bicyclic radicals from OH-toluene reactions. J. Amer. Chem. Soc. 125, 12655-12665.

Surratt, J. D., Murphy, S. M., Kroll, J. H., Ng, N. L., Hildebrandt, L., Sorooshian, A., Szmigielski, R., Vermeylen, R., Maenhaut, W., Claeys, M., Flagan, R. C. and Seinfeld, J. H. (2006) Chemical composition of secondary organic aerosol formed from the photooxidation of isoprene. J. Phys. Chem. A 110, 9665-9690.

Szmigielski, R., Surratt, J. D., Gómez-González, G., Van der Veken, P., Kourtchev, I., Vermeylen, R., Blockhuys, F., Jaoui, M., Kleindienst, T. E., Lewandowski, M., Offenberg, J. H., Edney, E. O., Seinfeld, J. H., Maenhaut, W. and Claeys, M. (2007) 3-Methyl-1,2,3-butanetricarboxylic acid: An atmospheric tracer for terpene secondary organic aerosol.
Geophys. Res. Lett. 34, L24811, doi:10.1029/ 2007GL031338.

Wan, E. C. H. and Yu, J. Z. (2007) Analysis of sugars and sugar polyols in atmospheric aerosols by chloride attachment in Liquid Chromatography/Negative Ion Electrospray Mass Spectrometry. Environ. Sci. Technol. 41, 2459-2466.

Wang, W., Kourtchev, I., Graham, B., Cafmeyer, J., Maenhaut, W. and Claeys, M. (2005) Characterization of oxygenated derivatives of isoprene related to 2-methyltetrols in Amazonian aerosols using trimethylsilylation and gas chromatography/ion trap mass spectrometry. Rapid Commu. Mass Spectrom. 19, 1343-1351.

Wang, W., Wu, M. H., Li, L., Zhang, T., Liu, X. D., Feng, J. L., Li, H. J., Wang, Y. J., Sheng, G. Y., Claeys, M. and Fu, J. M. (2008) Polar organic tracers in $\mathrm{PM}_{2.5}$ aerosols from forests in eastern China. Atmos. Chem. Phys. 8, 7507-7518.

Yassaa, N., Peeken, I., Zöllner, E., Bluhm, K., Arnold, S., Spracklen, D. and Williams, J. (2008) Evidence for marine production of monoterpenes. Environ. Chem. 5, 391-401.

Yokouchi, Y. and Ambe, Y. (1988) Diurnal variations of atmospheric isoprene and monoterpene hydrocarbons in an agricultural area in summertime. J. Geophys. Res., [Atmos.] 93, 3751-3759.

Yokouchi, Y., Li, H. J., Machida, T., Aoki, S. and Akimoto, H. (1999) Isoprene in the marine boundary layer (Southeast Asian Sea, eastern Indian Ocean, and Southern Ocean): Comparison with dimethyl sulfide and bromoform. $J$. Geophys. Res., [Atmos.] 104, 8067-8076.

Yttri, K. E., Dye, C. and Kiss, G. (2007) Ambient aerosol concentrations of sugars and sugar-alcohols at four different sites in Norway. Atmos. Chem. Phys. 7, 4267-4279.

Yu, J., Griffin, R. J., Cocker, D. R., III, Flagan, R. C., Seinfeld, J. H. and Blanchard, P. (1999) Observation of gaseous and particulate products of monoterpene oxidation in forest atmospheres. Geophys. Res. Lett. 26, 1145-1148. 